\title{
Make It Right: The Agency of Architecture in the Image
}

\author{
Sanja Rodeš, Griffith University, Australia
}

\begin{abstract}
In 2007, the actor Brad Pitt and the architectural firms GRAFT and William McDonough \& Partners commenced a project in the Lower Ninth Ward, a suburb of New Orleans. The idea was to build new houses for those residents who had lost their homes to Hurricane Katrina two years before. The Make It Right Foundation commissioned twenty-one architectural firms to design green, flood-resistant family houses. This paper aims to investigate how the reconstruction of the Lower Ninth Ward became an international media event and the type of problems it exposes in the domain of contemporary architecture. An attempt is also made to define and investigate the impact of a celebrity leading figure on both the designing and reconstruction processes, as well as possibly the new agency of image in architecture and architecture itself: architectural images as a recognizable media that are used as a tool for marketing and branding. Using the discourse analysis as a method of research, this paper explores the confluence of international attention and image consciousness, where the architectural image is used as a powerful tool of mass media in an attempt to communicate the altered representation of this New Orleans suburb.
\end{abstract}

Keywords: Image, Reconstruction, Media, Architecture, Iconicity, New Orleans, Make It Right, Brad Pitt

\section{On Make It Right}

I n 2007, Brad Pitt started a project in the Lower Ninth Ward, New Orleans, to produce new houses for the residents who had lost their homes to Hurricane Katrina two years prior. After the actor visited the suburb and noted the slow pace of recovery and the lack of a rebuilding process in the area, he started a rebuilding initiative. The foundation is called "Make It Right" (hereafter, MIR), and it is a non-profit organization committed to the provision of sustainable housing for communities in need. Brad Pitt chose New Orleans and the Lower Ninth Ward to become active for the first time in the post-disaster reconstruction on the scale of the MIR project. The foundation committed to building affordable, green-design houses in order to prove that green housing can be affordably built anywhere. ${ }^{1}$ The houses are available to the people who lived in the Lower Ninth Ward, as well as to their relatives, along with teachers and the first responders (firefighters, police officers, and emergency medical technicians). ${ }^{2}$ The Foundation continued to expand its interest areas after its initial action in New Orleans and is currently engaged with projects in Kansas City, Newark, and Fort Peck, demonstrating an undiminished interest in assisting communities in need by providing sustainable housing designed in accordance with the Leadership in Energy \& Environmental Design (LEED) platinum certification. ${ }^{3}$ The rebuilding of Lower Ninth Ward in New Orleans is the only post-disaster

\footnotetext{
1 “History," Make It Right, Accessed April 9, 2013, http://makeitright.org/about/history/.

${ }^{2}$ On November 9, 2012, the list of the future homeowners expanded from previous residents of the Lower Ninth Ward and their relatives to teachers, firefighters, police officers, and emergency medical technicians. The interest of former residents to return was significantly lower after 86 houses had been built, so MIR opened to new potential residents in order to sell the remaining houses they had committed to rebuild, and in order to "benefit the burgeoning community." (See Doug MacCash, "Brad Pitt's Make It Right Affordable Houses now Available to Teachers, First Responders," NOLA, Accessed August 5, 2013, http://www.nola.com/arts/index.ssf/2012/11/brad_pitts_make_it_right_affor.html).

${ }^{3}$ The project in Kansas City aimed to build units for 150 residents, out of which 50 were for veterans, seniors, and people with special needs; the project in Newark produced housing for disabled veterans, and the one in Fort Peck, housing for Sioux and Assiniboine tribes. For more information, see "Newark," Make it Right, Accessed July 9, 2013, http://makeitright.org/where-we-work/newark/, "Kansas City," Make It Right, Accessed July 9, 2013, http://makeitright.org/where-we-work/kansas-city/ and "Fort Peck," Make It Right, Accessed July 9, 2013, http://makeitright.org/where-we-work/montana/.
}

The International Journal of the Image

Volume 4, 2014, www.thelearner.com, ISSN 2154-8560

(C) Common Ground, Sanja Rodeš, All Rights Reserved

Permissions: cg-support@ commongroundpublishing.com 
reconstruction project undertaken by MIR, however all of their projects focus on attracting media attention and catalyzing the investment in their respective communities. ${ }^{4}$

Six months after Hurricane Katrina, the Lower Ninth Ward was the last area in New Orleans still under a curfew, mostly because of the great devastation and the lack of essential services, as well as the depopulation of the area. ${ }^{5}$ It was one of the areas that was hit the hardest by the hurricane, and the failure of its levee and the resulting catastrophic destruction was the subject of a major outcry in the international media. ${ }^{6}$

Distinguishing features of the Lower Ninth Ward were its high crime rate-homicide rates were among the highest in the city - and the level of poverty of its low-income families. ${ }^{7}$ The Lower Ninth Ward was regarded as "the murder capital of the murder capital"; 8 while the homicide rates in New Orleans 2007 were approximately ten times higher than the national average. ${ }^{9}$ The previously mentioned suburb was the last that developed in the city; it started developing in the $1950 \mathrm{~s}$, and it was affordable for the city's poorest residents. ${ }^{10}$ By 2000 , approximately $90 \%$ of its inhabitants were African-American and 33\% lived in poverty. ${ }^{11}$ The lack of a reconstruction initiative by the city in an area of such a strained socio-political structure seemed to be a racial issue.

The Bring New Orleans Back Commission established under Clarence Ray Nagin, Jr. (the Mayor of New Orleans from 2002 to 2010) suggested a plan for recovery in December 2005. According to the plan, the former residents of the areas that had suffered the most severe damage in the hurricane would not be able to return to their home neighborhoods, nor to begin rebuilding their homes, for four months. In that time, former residents would have to demonstrate that at least half of them would be willing and able to return. ${ }^{12}$ Residents of neighborhoods unable to do so would have their suburbs reduced in size or turned in to green spaces. ${ }^{13}$ Having only four months to demonstrate both sufficient funds to rebuild and a will to return was particularly difficult for the Lower Ninth Ward's low-income families.

The less-transparent outcome of this plan would be a depopulation of the parts of New Orleans characterized by poverty. Furthermore, rebuilding to ensure a more favorable image for the area and the city would be achieved by allowing only the wealthiest residents to return. Being predominantly populated with low-income families, the Lower Ninth Ward was expected to be

\footnotetext{
4 “Kansas City," Make It Right.

5 “Lower Ninth Ward," Wikipedia, Accessed July 9, 2013, http://en.wikipedia.org/wiki/Lower_Ninth_Ward.

${ }^{6}$ The Industrial Canal levee that was built to protect the Lower Ninth Ward failed, causing major damage and wiping out almost the entire area. Brad Pitt, in his personal letter of invitation on the MIR official web site called this event "the largest engineering disaster" the US had ever experienced. ("Letters of Invitation" in "Design Guidelines," Make It Right, Accessed July 29, 2013, http://makeitright.org/wp-content/uploads/2012/10/Design-Guidelines-Packet-Web.pdf).

7 Juliette Landphair, " 'The Forgotten People of New Orleans': Community, Vulnerability, and the Lower Ninth Ward," The Journal of American History, 94 (Dec. 2007): 837-45, accessed May 10, 2013, http://www.journalofamericanhistory.org/projects/katrina/Landphair.html.

${ }^{8}$ Ibid.

${ }^{9}$ Alexander Eichler, "Super Bowl 2013: New Orleans Readers Show Off Their City," Huffington Post, accessed May 13, 2013, http://www.huffingtonpost.com/2013/02/01/super-bowl-2013-new-orleans_n_2599751.html. and "Murders in New Orleans were slightly fewer in 2012 than in 2011," NOLA, accessed August 3, 2013, http://www.nola.com/crime/index.ssf/2012/12/murders_in_new_orleans_were_sl.html.

10 "Through the Eye of Katrina: The Past as Prologue?" The Journal of American History, 94 (Dec. 2007): 693-876, accessed May 13 , 2013 , http://www.journalofamericanhistory.org/projects/katrina/gloss/_neighborhood.html?key=lower_ninth

${ }^{11}$ Landphair, "The Forgotten People of New Orleans."

${ }^{12}$ Kate Randall, "City Residents Denounce 'Bring New Orleans Back' Rebuilding Plan. Remaking New Orleans for the Wealthy,” World Socialist Web Site, accessed May 9, 2013, http://www.wsws.org/en/articles/2006/01/newo-j14.html.

${ }^{13}$ Milla Harrison-Hansley, The Lost city of New Orleans, videorecording, written/produced by Milla Harrison-Hansley (Frenchs Forest, NSW: BBC Active, 2006). The "Bring New Orleans Back" plan was supported by the fact that the hardest-struck areas were below sea level (for example, the Lower Ninth Ward), which, together with the Mississippi River bordering them, represent a high risk of flooding and another disaster. The city experts analyzed the situation and concluded that the best way to partially block strong hurricane winds would be to restore green spaces in the mentioned areas, and not to risk more victims in case of another hurricane.
} 
turned in to parkland according to this plan. However, the former residents opposed the plan strongly, claiming their land back and the opportunity to rebuild their properties even without the "critical mass" required by the plan. Consequently, the former residents required a new plan addressing the rebuilding process to better suit low-income families. ${ }^{14}$ Despite the number of previous residents of the Lower Ninth Ward not returning, a number of former residents were multi-generational families with high levels of homeownership and were determined to return to their old neighborhood. ${ }^{15}$ Their claims were based on the "right of return" argument made by progressive and radical-left activists. ${ }^{16}$ As a result, the area emerged as "a compelling touchstone" of the aforementioned argument because of the predominantly black residents and the high homeownership level. ${ }^{17}$

Two years after the announced plan by the Bring New Orleans Back Commission, and due to the lack of initiative by the city and state government to solve the problem, MIR commissioned twenty-one architectural firms to rebuild the Lower Ninth Ward. In addition, the City of New Orleans and private groups developed more than fifteen master plans for the Lower Ninth Ward, ranging from rebuilding the suburb as a green area to developing the commercial zone. ${ }^{18}$ While the city masterplans dealt primarily with parking and zoning etc., the foundation focused on building the individual houses on the parcels of land owned by the people of the Lower Ninth Ward. ${ }^{19}$ The participating architects were selected by GRAFT architects, William McDonough \& Partners, John Williams, Brad Pitt, and Reed Kroloff (former Dean of the Tulane School of Architecture at Tulane University in New Orleans), and were required to design new sustainable houses for the Lower Ninth Ward. ${ }^{20}$ The architects volunteered their time to design contemporary green houses, and after the first of two phases, schematic designs were submitted. Make It Right's Executive Architect (John C. Williams Architects are the MIR Executive Architecture Firm) along with Director of Construction, Craig Turner, evaluated the designs based on sustainability, affordability, and replicability, and provided feedback to design architects, who then incorporated the feedback within two weeks. ${ }^{21}$ In order to make the houses more sustainable, they were designed according to the LEED for Homes and to the National Association of Home Builders (NAHB) certification program, and were also inspired by Cradleto-Cradle thinking. ${ }^{22}$

\footnotetext{
${ }^{14}$ Randall, "City Residents Denounce 'Bring New Orleans Back'."

15 "Lower Ninth Ward Planning District Rebuilding Plan," in "Design Guidelines," Make It Right.

${ }^{16}$ Cedric Johnson, ed., The Neoliberal Deluge Hurricane Katrina, Late Capitalism, and the Remaking of New Orleans (Minneapolis: University of Minnesota Press, 2011), 188.

${ }^{17}$ Ibid.

18 "Design FAQ - New Orleans," Make It Right, accessed August 2, 2013, http://makeitright.org/what-weknow/library/article/design-faq/.

${ }^{19}$ Ibid. The target area of the MIR intervention was a 20-block radius in the Lower Ninth Ward, the part where 4000 homes had been destroyed in Hurricane Katrina.

${ }^{20}$ Invited architects who submitted their designs were: MVRDV (Rotterdam, Netherlands), Pugh \& Scarpa (Santa Monica, US), Building Studio (New Orleans, US), Elemental (Santiago, Chile), Ray Kappe (Berkley, US) and William McDonough \& Partners (Charlottesville, US). Architects who submitted and had their designs selected by future homeowners were: Adjaye Associates (London, England), Billes Architecture (New Orleans, US), BNIM (Kansas City, US), Concordia (New Orleans, US), Constructs (Accra, Ghana), Eskew \& Dumez \& Ripple (New Orleans, US), GRAFT (Berlin, Germany), Kieran Timberlake (Philadelphia, US), Morphosis (Santa Monica, US), Shigeru Ban Architects (Tokyo, Japan), Trahan Architects (Baton Rouge, US), Hitoshi Abe (Sendai, Japan), BILD (New Orleans, US), Gehry and Partners (Los Angeles, US), and Waggoner and Ball (New Orleans, US). For more information, see "Architects," Make It Right, accessed April 10, 2013, http://makeitright.org/what-we know/library/article/architects/.

${ }^{21}$ GRAFT Architects were coordinators of Schematic Design phases. See "Letters of Invitation", "Make It Right; A. Mission Statement: New Homes for New Orleans" and "Project Information” in "Design Guidelines," Make It Right. For the full list of MIR staff, see "Staff," Make It Right, Accessed July 29, 2013, http://makeitright.org/about/staff/.

${ }^{22}$ For more information on LEED Certification, see "LEED Certification information,” NRDC, accessed April 9, 2013, http://www.nrdc.org/buildinggreen/leed.asp. For information on the NAHB Certification Program, see National Association of Home Builders, accessed July 29, 2013, http://www.nahb.org/generic.aspx?genericContentID=194088. See detailed information on Cradle-to-Cradle thinking at "Cradle to Cradle", Make It Right, accessed April 9, 2013, http://makeitright.org/c2c/ and "Cradle to Cradle and Material Selection Guidelines" in "Design Guidelines," Make It Right. This thinking was developed and popularized by architect William McDonough and chemist Michael Braungart in
} 
The first intervention of MIR, which preceded the actual house designing, was the Pink Project art installation organized in 2007, which consisted of 150 pink fabric structures scattered around the devastated site of the Lower Ninth Ward. The structures were placed randomly in the area in order to symbolize the destruction after Hurricane Katrina, and the original aim was to attract attention and to raise the funds necessary for the house rebuilding. The bright pink tents were expected to be replaced with houses as they are built, and the structures represented a powerful visual reminder of the catastrophe that had occurred. This art installation significantly contributed to the creation of the Lower Ninth Ward's image as a post-disaster area in need of reconstruction, instead of its previous image as a poor (and neglected) suburb destined for parkland, which would essentially cloak the area's rich history. According to the web site of the GRAFT architects, "through the immediate potency of the spectacle, aided by local and global media, it attempts to disassociate itself from the negative connotations of that which has failed." 23

The Pink project was the first step in the overall process of creating the new image of Lower Ninth Ward and attracting further interest and potential investment in the area. By creating an image both in the media and in spectacle, the MIR intervention announced the reconstruction with the Pink Project as the first phase of the entire project, attracting media attention to the event. The project managed to raise almost four times more funds than the initial investment, which also consisted of Brad Pitt's personal investment of five million dollars. ${ }^{24}$ The money was gathered via individual donors, corporations, and foundations. According to the official MIR web site, the donated money was and continues to be spent on building sustainable houses and on educating others in affordable and green-design building methods.

The MIR project received very extensive media attention, appearing in design magazines, such as Azure and Architectural Digest, and in popular TV shows, including Larry King Live, Holmes on Homes, and the Ellen DeGeneres Show. ${ }^{25}$ Brad Pitt was praised for his generous act and interest in the matter, but at the same time he was criticized by the architectural press over the actual urban renewal of the Lower Ninth Ward and the rebuilding of the new neighborhood. The attention the project received in the media reached its peak after the project was announced; however, with the support of other celebrities along with Brad Pitt, the project continues to reappear in the media. ${ }^{26}$

The MIR Foundation wasn't the only organization aiming to contribute to the new (architectural) image of post-Katrina New Orleans. The interventions of New Orleans Area Habitat for Humanity (NOAHH), along with The Bring New Orleans Back Commission were just some of the initiatives responsible the rebuilding of the city. ${ }^{27}$ An exhibition of architectural projects called "A Newer New Orleans" held in the Building Museum in Washington D.C. in July 2006 featured six proposals by American and Dutch firms. ${ }^{28}$ Furthermore, two architectural

their book published in 2002: William McDonough and Michael Braungart, Cradle to Cradle: Remaking the Way We Make Things (New York: North Point Press, 2002). It is the thought process based on the natural cycles of living organisms and the circulation of food and waste incorporated into the designing process. ("Cradle to Cradle and Material Selection Guidelines," Make It Right).

23 “The Pink Project," GRAFT, accessed April 9, 2013, http://www.graftlab.com/en_index.htm?f=true\#/alph312pink.

${ }^{24}$ Rowan Moore, "Brad the Builder in New Orleans," The Guardian, accessed April 9, 2013, http://www.guardian.co.uk/artanddesign/2010/mar/14/brad-pitt-architecture-new-orleans.

${ }_{25}$ Johnson, The Neoliberal Deluge Hurricane Katrina, Late Capitalism, and the Remaking of New Orleans, 187, and Doug MacCash, "Make It Right at a Crossroads Halfway Through Its Lower $9^{\text {th }}$ Ward Rebuilding Project," NOLA, accessed August 28, 2013, http://www.nola.com/katrina/index.ssf/2012/03/make_it_right_at_a_crossroads.html.

${ }^{26}$ For example, a last year event organized by Brad Pitt supported by a number of celebrities attracted media attention and significant funds. "A Night to Make It Right" event was hosted by Ellen DeGeneres and Brad Pitt on March 10, 2012, which raised more than 5 million dollars. For more information, see Jerry McLeod, "Brad Pitt and Ellen DeGeneres to Host a Star-studded Fundraiser in New Orleans," NOLA, accessed July 30, 2013, http://www.nola.com/celebrities/index.ssf/2012/01/brad_pitt_and_ellen_degeneres.html.

${ }^{27}$ For more information about NOAHH, see: “About Us," New Orleans Area Habitat for Humanity, accessed August 28, 2013, http://www.habitat-nola.org/about/.

${ }^{28}$ Karen Kingsley, "New Orleans Architecture: Building Renewal," The Journal of American History, 94 (Dec. 2007$)$ : 716-25, accessed November 10, 2013, http://www.journalofamericanhistory.org/projects/katrina/Kingsley.html. 
competitions were held at the Tulane School of Architecture, and the designs proposed were contemporary in style and modern interpretations of vernacular house typologies. There were a number of other attempts which questioned the new image and participated in the creation of post-Katrina New Orleans, Make It Right being just one of them. However, in its attempt to contribute to, and create, the new image, the MIR Foundation excelled and became the most recognizable in media.

\section{The Image, the Icon}

According to Terry Smith and Hans Ibelings, it is arguable that the iconic buildings are the architectural representation of the connection between architecture, economy, and politics. ${ }^{29}$ Ibelings compared the architecture of the 1990s and 2010, arguing the persistence of the iconicity in architecture: "Not only are the same famous names still famous, but the groove in which architecture finds itself is still that of starchitects, icons, Bilbao effects." ${ }^{30}$ Despite the fact that architecture in 2010 can hardly be reduced to simply - iconic, these icons have prevalence in media, as they are the focus of a number of discussions and articles in architectural magazines and books. Furthermore, Smith uses the term "iconomy" in order to explain the process in which the architectural projects and their imagery in the media are used as marketing and branding tools and receive the exchange value within the economy. ${ }^{31}$ The buildings that are part of iconomy are typically designed with spectacular facades and sculptural forms, and are architectural icons. Images of these projects are circulating and reappearing in the media; "On the Internet, the everburgeoning volume of these architectural images constitutes a visual plastic soup that permanently pollutes the digital information oceans." 32 Smith outlines a number of examples of iconic buildings designed by famous architects which succeeded in achieving a significant media impact and changing the image of their respective cities. ${ }^{33}$ The question that is posed here is, does this process have any conceptual similarity with the MIR project in New Orleans?

In the rebuilding project, MIR invited internationally renowned architects to design the houses in the Lower Ninth Ward. Some of the architects were famous to an "architectural" audience (MVRDV, Shigeru Ban, Morphosis, etc.), and others to a non-architectural audience (Frank Gehry is an example of the starchitect in the team). Make It Right argues that inviting a number of famous architects to the project was a way to provide the future homeowners with designs of the highest quality; however, this action drew significant attention to the project. On analyzing the outcome of the MIR action rather than Brad Pitt's intentions, it is notable that the attention achieved was based equally on the event of Hurricane Katrina, on the name and image of Brad Pitt, and on the images of the new house designs. The project was covered with excessive imagery in the media, mostly of the new houses, but also of images of Brad Pitt

\footnotetext{
${ }^{29}$ For more information, see Terry Smith, The Architecture of Aftermath (Chicago: University of Chicago Press, 2006), and Hans Ibelings and Powerhouse Company, Shifts: Architecture After the 20th Century (Amsterdam: Architectural Observer, 2012).

${ }^{30}$ Ibelings and Powerhouse Company, Shifts: Architecture After the 20th Century, 18. For the explanation on the term of 'starchitects', see Gabriella Lo Ricco and Silvia Micheli, Lo Spettacolo Dell'architettura: Profilo Dell'archistar, Sintesi (Milano: B. Mondadori, 2003). Authors mention the term "starchitects" (Italian - "archistar") to stress that architects and architecture have become a part of show business.

${ }^{31}$ The term "iconomy" was explained in Smith's book The Architecture of Aftermath, 5-8. In recent decades, iconomy acquired a significant relationship with spectacle. Iconomy is connected with the iconic in architecture, as an "imageboost" in order to achieve the "economy-boost" (or profit).

According to Smith, the iconic image generates variety of values. In the globalized state of capital, the emphasis is on an economic value. "Not, however, simply as money - although that is a major measure of how its capacity stands to other economic agents - but as itself: an iconotype spins off countless images of itself, innumerable repetitions, along with multitudes of associated images and values." Ibid, 22-23.

${ }^{32}$ Ibelings and Powerhouse Company, Shifts: Architecture After the 20th Century, 47.

${ }^{33}$ See Smith, The Architecture of Aftermath, 7.
} 
together with the African-American former residents of the Lower Ninth Ward. ${ }^{34}$ The images were used to stimulate attention in order to gather funding and to further Brad Pitt's ambitions to make an extensive impact and educate a wide audience in affordable sustainable construction.

The process of utilizing imagery of the MIR project in order to gather funding can be compared with the process of entering into iconomy. The MIR project managed to excel as a media icon; in addition to the media event of Hurricane Katrina and the attention towards Brad Pitt, the house designs were pulled into a story. The new houses seem to have created a spectacle resting on the value of celebrity, bouncing the attention back and forth from the empty parcels of Lower Ninth Ward and some of the devastated houses that can still be found in the area. Iconicity and icons are arguably based on the image - and it can be said that the icon is a meaningful image. "In late capital, however, an iconotype is an image that, usually through repetition, stands out in the image flow, halts the incessant circulation, and draws fixity to itself. It maintains its iconicity not by being different from the nature of other images in the flow, but by being more excessively like them." 35 The MIR project contributed to the "image flow" for the images of the superb house designs.

Further, the designs were equally subjected to the media attention the project achieved and a relationship between architecture and media - a spectacle - was formed. Houses were arguably designed to respond to the already existing media attention and to create a recognizable image in the media. According to Guy Debord, mass media are the "most stultifying superficial manifestation" of the spectacle; in this case, mass media represent the crucial element of its creation. ${ }^{36}$ The parallel that Foster drew between the Debord's widely cited "the spectacle is capital accumulated to the point where it becomes image" and cities today is the capacity of spectacular architecture "to assist in the corporate "revival" of the city." 37 Foster used the example of spectacular cultural buildings which have the tourist awe and participate in the aforementioned revival; the new part of the Lower Ninth Ward suburb acted as a (media) icon, expressing conceptual similarities to the spectacular representation typical for iconic architectural projects, particularly in terms of the attention it attracted. The project managed to achieve media iconicity by creating a spectacle and, at the same time, attempting to change the image of the suburb and attracting a number of tourists.

The designing of the Lower Ninth Ward reveals the fine line connection between celebrities, media, and "fashionable", high-end designs of houses, where all three seem to be part of the one realm. Media attention is what both celebrities and house designs by world-known architects have in common. A number of the invited architects (particularly those appearing often in the media) have their own teams who manage their media relations, illustrating the importance of mass media in their business.

Yet, in order to fully explore the relationship between celebrity and architects via the media, it is necessary to be more specific in terms of the type of press coverage received. It is not just professional journals that provide significant press coverage for architects, but the popular media. In order for an architect to establish the broad recognition that is associated with celebrity, they must move beyond their professional circle and into the mainstream media. Although professional credit is the catalyst towards fame, it is not the means by

\footnotetext{
${ }^{34}$ For example, just some of the sources that published material on the house Frank Gehry designed for Make It Right are: Lauren Grieco, "Frank Gehry: House for the Make It Right Foundation,” Designboom, accessed December 2, 2013, http://www.designboom.com/architecture/frank-gehry-house-for-the-make-it-right-foundation/, Amy Frearson, "Duplex by Frank Gehry for Make It Right," Dezeen, accessed December 2, 2013, http://www.dezeen.com/2012/07/16/duplex-byfrank-gehry-for-make-it-right/ and Karissa Rosenfield, "Make It Right Completes Frank Gehry-Designed Duplex," Archdaily, accessed December 2, 2013, http://www.archdaily.com/255147/make-it-right-completes-frank-gehrydesigned-duplex/.

${ }^{35}$ Smith, The Architecture of Aftermath, 22.

${ }^{36}$ Guy Debord, The Society of the Spectacle, trans. Donald Nicholson-Smith (New York: Zone Books, 1994$), 24$.

${ }^{37}$ Ibid., 34, and Hal Foster, Design and Crime: and Other Diatribes, (London: Verso, 2002), 41.
} 
which it is achieved; rather it is recognition by non-architects that catapults an individual into the limelight (Drummond 2012, 84).

The attention that the MIR project received in both the popular and architectural media was the confluence of international media attention and architectural images. Make It Right has its own media page on its official web site where the organization emphasizes the importance of the media in order to share the project's progress and to reach a wide audience, and states that it receives a high volume of enquiries. ${ }^{38}$ If the aforementioned media attention (as the type of recognition associated with celebrity status) is equally crucial in the creation of starchitecture and starchitects, it is possible to argue that the MIR project produced starchitecture, but not necessarily designed by starchitects. Starchitecture and iconic architecture are synonyms for the spectacular architecture that is defined by image and recognized by non-architectural media, and is the architecture that has value in iconomy. The MIR project is an example of a media-charged architectural event resting on the value of celebrity and managing to attract the attention of mainstream media directed more towards house designs and reconstruction than towards their architects.

There is also a link between buildings, architecture, and financial capitalism that Ibelings points to: "Buildings also belong to the category of products on which financial capitalism thrived ... all the (in this case paid) parties who make buildings, starting with architects, ensure that those who own the buildings become wealthier from it ... Because construction alone will not make you seriously rich." ${ }^{39}$ Even though the MIR project was not aiming at making anyone rich, the goal of the action was fund-raising. Ibelings argues the correlation between construction in financial capitalism and profit, a correlation which is represented in the image of architecture as well and is reflected in the MIR reconstruction project. Further to the matters of image, Smith stresses that "architecture has for centuries supplied the image economy (the iconomy, for short) with key markers, with built stakeholders that seek to arrest the image flow, to tie it down to a place, a brand, and a purpose. These are complex relations, and cannot, even in the age of the spectacle, be reduced to a simple idea of the triumph of the image over the material, of spectacle over use. $" 40$

\section{The Agency of Architecture in Make It Right}

The MIR Foundation encouraged modern interpretations of local house typologies. These designs included the shotgun house (generally a long, narrow house facing the street with rooms arranged in a single row and with a porch at the front); the camel-back shotgun house (the regular shotgun design with an additional second story at the rear of the house); and the Creole Cottage (a single story, ground-level house built close to the front property line).$^{41}$ The Foundation was oriented on providing the two types of housings: single-family unit and a duplex house. Elements such as porches, balconies, front "stoops", pitched roofs, high ceilings, double-hung windows etc., were encouraged in order to contribute to community building and to the social connectedness of the suburb. These were common design features in the pre-Katrina vernacular

\footnotetext{
38 "Media," Make It Right, accessed August 5, 2013, http://makeitright.org/media/.

${ }^{39}$ Ibelings and Powerhouse Company, Shifts: Architecture After the 20th Century, 32.

${ }^{40}$ Terry Smith, "Spectacle Architecture Before and After Aftermath: Situating the Sydney Experience," in Anthony Vidler, Architecture Between Spectacle and Use, Clark Studies in the Visual Arts (Williamstown, Mass., New Haven: Sterling and Francine Clark Art Institute; Distributed by Yale University Press, 2008), 3.

${ }^{41}$ For more information on the Shotgun house type, see "Shotgun House," KnowLA. Encyclopedia of Lousiana, accessed July 16, 2013, http://www.knowla.org/entry/570/. See also Jay D. Edwards, "The Origins of Creole Architecture,"।

Winterthur Portfolio 29, no. 2/3 (Summer-Autumn, 1994): 155-189. Published by: The University of Chicago Press on behalf of the Henry Francis du Pont Winterthur Museum, Inc., accessed April 10, 2013, http://www.jstor.org/stable/1181485.
} 
surroundings of the Lower Ninth Ward. The MIR house designs were meant to weather the next storm, and to be energy efficient, with residents expected to save significantly on energy bills. ${ }^{42}$

Another important aspect of the MIR project is assisting people from the Lower Ninth Ward to purchase the houses. The house prices range from an average of $\$ 150,000$ for a single house to an average of $\$ 200,000$ for a duplex, and MIR subsidizes future homeowners up to $\$ 75,000 .{ }^{43}$ The future owners are free to choose the house design and color, so the number of duplicated houses around the site is fully dependent upon their preferences. Furthermore, MIR works with the Lower Ninth Ward community in creating the playgrounds, gardens, and sustainable street projects, amongst others, to develop the sense of the neighborhood, according to the official web site. In addition, MIR works with the City of New Orleans to develop a sustainable street plan.

One of the controversies about the MIR project is a collision between (the mostly) internationally renowned architects who designed the new houses and the desire to actually preserve and renew the traditional urban surroundings of the New Orleans suburb and the shotgun house type itself. The controversy represents the colliding of the images of superb new houses with the reality of the Lower Ninth Ward's surroundings and its pre-Hurricane Katrina context. ${ }^{44}$ The devastated suburb was arguably marked with nostalgia for a community spirit disrupted by the hurricane, which was a form of the image itself, and had an ideologically mediated relationship to the reality of the post-Hurricane Katrina city. Moreover, Taylor stresses that the "common belief that memory is an intrinsic part of the human condition of shock and loss gives form to a theory of how urban communities experience disaster." 45 The Hurricane Katrina and rebuilding of Lower Ninth Ward was marked by memory and nostalgia created after the disaster. The community spirit of the part of Lower Ninth Ward defined with MIR houses is somewhat a matter of criticism in the media for the original houses in the Lower Ninth Ward were local house typologies, which were lined up, similar in size, and with open porches that had an important social role. ${ }^{46}$ The new designs are contemporary in their design, elevated to different heights, with different roof pitches and porches not always equally visible or available. Make It Right adopted a house-by-house rebuilding strategy, and the houses designed were positioned differently in relation to the front yard, where MIR worked with current New Orleans zoning laws in an effort to move the homes as close to the street as possible. Some of the criticism the project received was directed towards the lack of a sense of neighborhood-the collision between the new houses and the sense of unity among them (Figure 1).

\footnotetext{
${ }^{42}$ For further information on design guidelines, see "Guidelines - New Orleans," Make It Right, accessed July 29, 2013, http://makeitright.org/what-we-know/library/article/guidelines-new-orleans/\#history.

${ }^{43}$ See MacCash, "Brad Pitt's Make It Right Affordable Houses Now Available to Teachers, First Responders," and "Guidelines - New Orleans," Make It Right.

${ }^{44}$ The controversy goes back to the shotgun house type history, with the number of theories developed about its origin. One of the theories suggests that shotgun house originated from the small rural Haitian folk cottage called the "ti kay." See Jay D. Edwards, "Shotgun: The Most Contested House in America," Buildings \& Landscapes: Journal of the Vernacular Architecture Forum, Vol. 16, No. 1 (Spring 2009), 62-96. Published by: University of Minnesota Press, accessed August 28, 2013, http://www.jstor.org.libraryproxy.griffith.edu.au/stable/27804896. In Haiti, the shotgun form was common for enslaved Africans, and once they "revolted in 1791, many European plantation owners fled to New Orleans, taking with them enslaved Africans still under their control. Many other free people of color migrated to New Orleans as well." ("Shotgun Houses," Greater New Orleans Community Data Centre, accessed April 10, 2013, http://www.gnocdc.org/tertiary/shotgun.html).

${ }^{45}$ William Taylor, "Shotgun Houses and Housing Projects: Architectural Typology and Memory Techniques of Two New Orleans Reconstruction Scenarios," Interstices 13. Technics, Memory and the Architecture of History (2012), 71-82, accessed November 20, 2013, http://interstices.ac.nz/wp-content/uploads/2013/05/INT13_02INV_01-Taylor.pdf.

${ }^{46}$ Rebecca Firestone, "New Orleans Post-Katrina: Making It Right?”, The Architect's Take, accessed April 11, 2013, http://thearchitectstake.com/editorials/new-orleans-post-katrina-making-right/.
} 


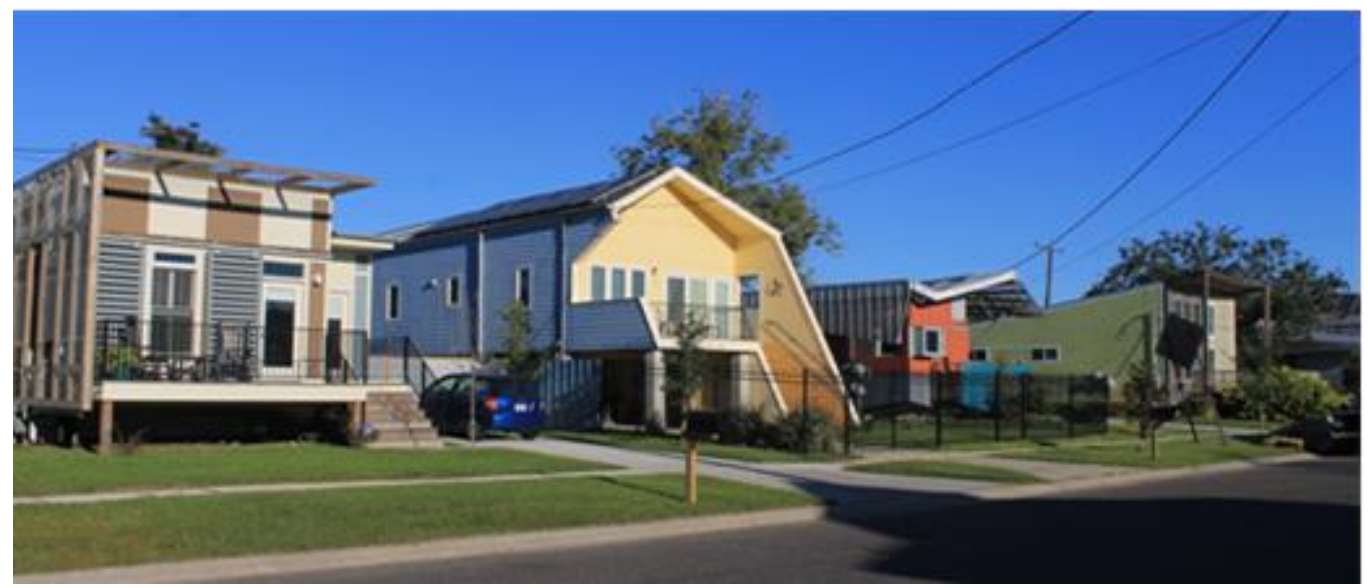

Figure 1 - Make It Right houses

\section{Source: Author.}

The new, colorful part of the Lower Ninth Ward is now a tourist attraction, with a "Hurricane Katrina tour" operating around the area. ${ }^{47}$ Its slight detachment from the reality of New Orleans' architecture serves the purpose of attracting the attention it needs to gather the necessary funding. This attention is achieved by circulating the architectural images of MIR's vision of a brighter future for the suburb. Johnson argues that there is "the local tourist industry's incessant effort to capitalize on nostalgia as a means of branding the city and securing its niche as an exotic, almost foreign destination for American vacationers." ${ }^{48}$ The author agrees that the MIR project in the Lower Ninth Ward is animated by nostalgia, arguably as a helpful means to fund-raise and achieve the desired media attention in the sensitive social environment.

There is also a correlation between the Lower Ninth Ward and the spectacle achieved by the Pink Project and the new houses designed - a correlation which adds to its tourist potential. Ibelings points to the relationship between spectacle and tourism: "Environments designed with and for a tourist gaze nearly always present a spectacle, a constructed image of reality that has to be beautiful, tidy and safe. The aversion to places experienced as touristy is usually inspired by the belief that they are devoid of authentic life." ${ }^{49}$ The part of the Lower Ninth Ward under reconstruction by MIR continuously attracts a number of tourists. Further to this argument: "Whereas the decaying camelbacks and Creole townhouses of pre-Katrina New Orleans carried an air of authenticity as well as gritty functionality, the emerging neo-New Orleans cityscape is a mix of novelty and mimicry that lacks the dense network of social relations and diversity that produced the city's unique urbanity." 50 The high-end MIR houses are in contrast with their surrounding empty parcels and the architectural features of the rest of the Lower Ninth Ward, yet they are an architectural representation of MIR's noble goal to help the citizens in need.

To further the discussion of the architectural aspects of the MIR project, it is noted that the house plans designed by the architects were returned to them for modification according to feedback from the MIR team, and in some cases the end product was significantly different to the original proposal. The question that can be asked here is this: What is the agency of architecture in this process and in the final image produced in the media? It seems that architects themselves do not possess much power in the process; the power lies with Brad Pitt and his team, who are

\footnotetext{
47 “Hurricane Katrina Tour," Gray Line, accessed August 29, 2013, http://www.graylineneworleans.com/hurricanekatrina-tour.html.

${ }^{48}$ Johnson, The Neoliberal Deluge Hurricane Katrina, Late Capitalism, and the Remaking of New Orleans, 211.

${ }^{49}$ Hans Ibelings, Supermodernism: Architecture in the Age of Globalization (Rotterdam: NAi, 1998), 155.

${ }^{50}$ Johnson, The Neoliberal Deluge Hurricane Katrina, Late Capitalism, and the Remaking of New Orleans, 214.
} 
responsible for the influx of money to the project. Generally speaking, the iconic buildings designed by world-known architects (and particularly starchitects) are rarely burdened with the same constraints and limitations presented to the architects of the MIR project; in how many instances would a duplex house designed by Frank Gehry-the great architect of the Guggenheim Museum in Bilbao, Spain — end up as half pink, half purple (Figure 2 and 3) ${ }^{51}$ The MIR team left the decision of choosing the exterior paint colors to the future homeowners, giving them power to influence the architecture of the houses they choose to live in. Could it be said that the architecture in this image was "toned down" in terms of its quality and power in order to be turned into an image (a MIR image) of political and social representation of the "new and improved" Lower Ninth Ward? The featured examples provided (Figures 2, 3, 4 and 5), are proof of that process. For instance, Shigeru Ban's house (Figure 4 and 5) was, at the level of a model proposed by architect, a minimalistic design with emphasized horizontal line and a tree included as its significant element. ${ }^{52}$ The simplicity and elegance disappeared to a significant extent after the house was built, for the horizontal lines were broken with the number of openings on the side and different vertical accents were made with the color finishing..$^{53}$ However, the MIR project did of course result in a number of quality houses. The previously mentioned examples aim to demonstrate that the images produced were also in service of the democratization of architecture and of its reduction to the more vernacular level, representing the reconciliation of a pure architectural image with the reality of MIR action.
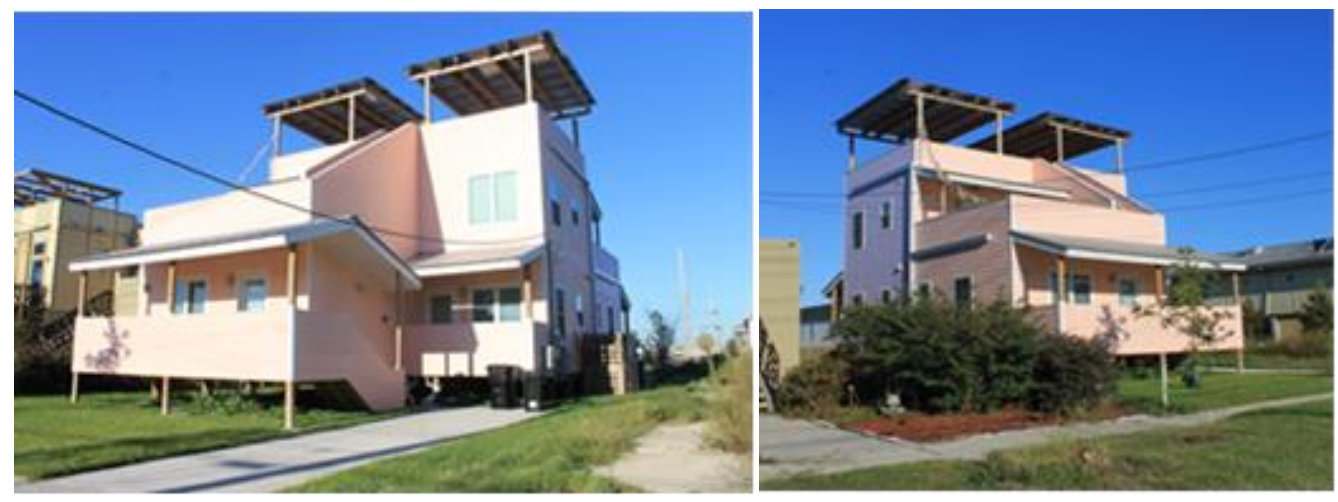

Figure 2 and 3: Frank Gehry's house design, pink/purple façades

Source: Author.

\footnotetext{
${ }^{51}$ The excerpt from the MIR press release: "I really believe in what Brad is doing for the community and was honored to be included," said Frank Gehry. "I wanted to make a house that I would like to live in and one that responded to the history, vernacular and climate of New Orleans. I love the colors that the homeowner chose. I could not have done it better." ("Electronic Press Kits," in "Media," Make It Right. Gehry's press release available at https://www.hightail.com/dl?phi_action=app/orchestrateDownload\&rurl=https\%3A\%2F\%2Fwww.hightail.com\%2Ftrans fer.php\%3Faction\%3Dbatch_download\%26batch_id\%3DWFJXb2VLU1BsamRYd3NUQw).

52 "Minimalism is here used to denote a movement, primarily in postwar America, towards an art - visual, musical,

literary or otherwise - that makes its statement with limited, if not the fewest possible, resources, an art that eschews abundance of compositional detail, opulence of texture, and complexity of structure." See Edward Strickland, Minimalism: Origins (Bloomington and Indianapolis: Indiana University Press, 2000), 7.

${ }^{53}$ For more pictures of the house designed by Shigeru Ban, see Jimmy Stamp, "The Making of a Make It Right House," Life Without Buildings, accessed August 20, 2013, http://lifewithoutbuildings.net/2009/07/the-making-of-a-make-itright-house.html.
} 

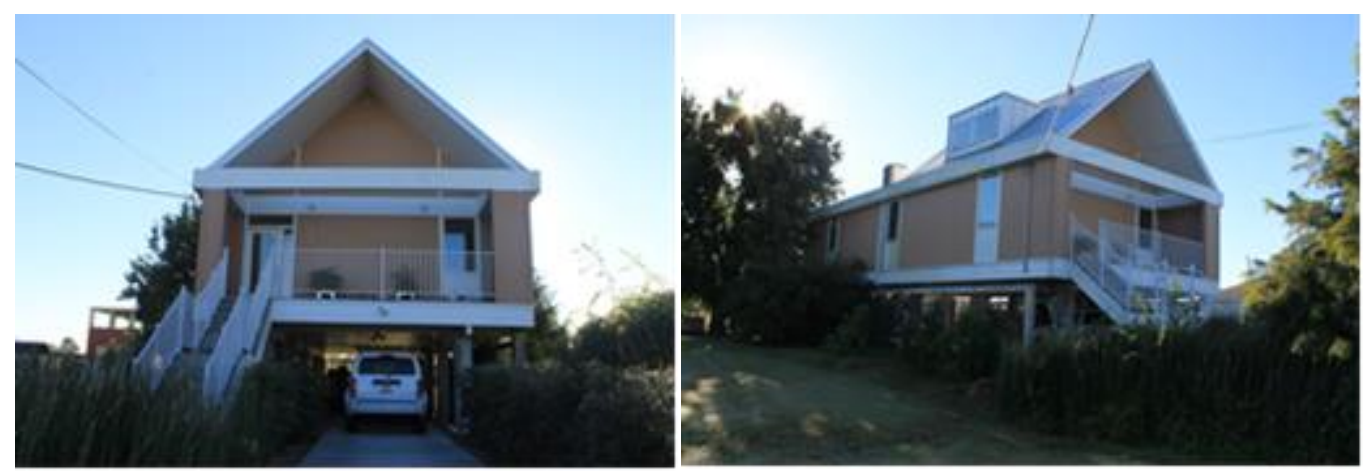

Figure 4 and 5: Shigeru Ban's house design

Source: Author.

\section{Remaking the Image}

What is the connection between the remaking of the image of the neighborhood and the high-end house projects designed for it? The ongoing construction and revitalization of the Lower Ninth Ward organized by MIR was expected to assign a new image to the Lower Ninth Ward, and to New Orleans indirectly. By changing the image of the demolished, neglected area into a place of renewal and reconstruction, MIR gave new architectural, social, and economic value to the Lower Ninth Ward. Ibelings argues that "architecture is like an index fossil of capital: where there is a lot of architecture, there is also a lot of money and economy grows (to which everything that is built and increases in value also contributes)." ${ }^{\circ 4}$ The singular images of new house projects designed by famous architects add a new layer to the area; the new part of the suburb constitutes new touristic spots and points of interest, while simultaneously providing another possible source of income for the city council.

In conclusion, the remaking of the Lower Ninth Ward - an area that had witnessed one of the biggest natural disasters in recent history-was mediatized. It was a spectacle created by superb architecture and reconstruction, and was one of the means for attracting attention to the MIR project. It appears that, in recent decades, in order to regard architecture/architects as high quality or famous, the relationship between media and architecture cannot be avoided, and architectural images are positioned as crucial to that relationship. By adding a new layer to the Lower Ninth Ward, the project is a visual representation of the attempt to break its connection with its shotgun racial history, and its reputation of a poor suburb with low-income families and high crime rates. The architectural images are the focal point in the process; the distinguishing element, however, is the limited freedom given to the architects who actually produce the images. The images in the MIR reconstruction are created equally as constructed social and political images - an answer to racial inequality and displacement — and architecture.

The MIR project demonstrates different power relations in comparison to what is usually seen when famous architects do the architecture; what seem to be different are the elements that hold the power. In this example, they are not the city governments or national companies. In the twenty-first century, and particularly in last few years, those willing to be involved with construction and having enough capital are also individuals and multinational companies. ${ }^{55}$ Their

\footnotetext{
${ }^{54}$ Ibelings and Powerhouse Company, Shifts: Architecture After the 20th Century, 40.

${ }^{55}$ See the attempt of IKEA to build the east part of London as an example of a multinational company involved in urban design and architecture: Olivia Williams, "Strand East: Ikea Hopes to Build an Entire London Neighborhood," The Huffington Post, accessed August 6, 2013, http://www.huffingtonpost.co.uk/2011/10/21/strand-east-ikeas-london_n_1023421.html.
} 
efforts in construction produce architectural images that often reflect additional values to architectural values, and these are a reflection of personal or shared company interests. The agency of architecture in the case of the Make It Right project represents a "measured amount" in order to produce the desired social and political construct, aiming to design an image for a broader audience rather than for a merely architectural audience or architecture-lovers. The image was constructed for those interested in the social and humanitarian aspect of the Make It Right action, aiming to create an impact of wider significance.

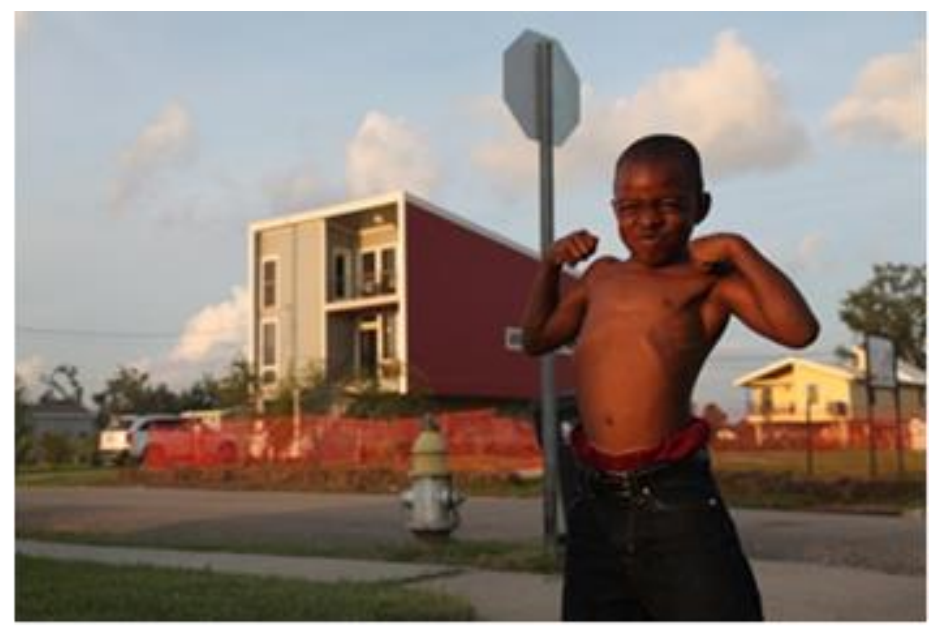

Figure 6: New houses in the Lower Ninth Ward and a local boy (in front of a home).

Source: Make It Right. 


\section{REFERENCES}

Aureli, Pier Vittorio. The Possibility of an Absolute Architecture. Writing Architecture Series. Cambridge, Mass.: MIT Press. 2011.

Debord, Guy. The Society of the Spectacle. Translated by Donald Nicholson-Smith. New York: Zone Books, 1994.

Drummond, Alanya. "Architects on the Cover of Time Magazine." The International Journal of The Image 2 (1) (2012): 83-91. Accessed April 18, 2013. http://ontheimage.com/journal/.

Edwards, Jay D. "Shotgun: The Most Contested House in America." Buildings \& Landscapes: Journal of the Vernacular Architecture Forum, 16 (1) (Spring 2009): 62-96. Accessed August 28, 2013. http://www.jstor.org.libraryproxy.griffith.edu.au/stable/27804896.

----. "The Origins of Creole Architecture." Winterthur Portfolio 29 (2/3) (Summer - Autumn, 1994): 155-189. http://www.jstor.org/stable/1181485.

Eichler, Alexander. "Super Bowl 2013: New Orleans Readers Show Off Their City." Huffington Post (February 2, 2013). Accessed May 13, 2013. http://www.huffingtonpost.com/2013/02/01/super-bowl-2013-neworleans_n_2599751.html.

Firestone, Rebecca. "New Orleans Post-Katrina: Making It Right?" The Architect's Take (January 25, 2011). Accessed April 11, 2013. http://thearchitectstake.com/editorials/new-orleans-post-katrina-making-right/.

Foster, Hal. Design and Crime: and Other Diatribes. London: Verso, 2002.

Frampton, Kenneth. Modern Architecture: A Critical History. World of Art. 4th ed. London, New York, N.Y.: Thames \& Hudson, 2007.

Frearson, Amy. "Duplex by Frank Gehry for Make It Right", Dezeen (July 16, 2012). Accessed December 2, 2013, http://www.dezeen.com/2012/07/16/duplex-by-frank-gehry-formake-it-right/,

Gray Line. "Hurricane Katrina Tour." Accessed August 29, 2013. http://www.graylineneworleans.com/hurricane-katrina-tour.html.

Grieco, Lauren. "Frank Gehry: House for the Make It Right Foundation," Designboom (July 17, 2012). Accessed December 2, 2013, http://www.designboom.com/architecture/frankgehry-house-for-the-make-it-right-foundation/,

Harrison-Hansley, Milla. The Lost City of New Orleans. Videorecording. Written/Produced by Milla Harrison-Hansley. 2006. Frenchs Forest, N.S.W.: BBC Active, 2006.

Ibelings, Hans, and Powerhouse Company. Shifts: Architecture After the 20th Century. Amsterdam: Architectural Observer, 2012.

Ibelings, Hans. Supermodernism: Architecture in the Age of Globalization. Rotterdam: NAi, 1998.

Johnson, Cedric. ed. The Neoliberal Deluge Hurricane Katrina, Late Capitalism, and the Remaking of New Orleans. Minneapolis: University of Minnesota Press, 2011.

Kingsley, Karen. "New Orleans Architecture: Building Renewal," The Journal of American History, 94 (Dec. 2007): 716-25. Accessed November 10, 2013, http://www.journalofamericanhistory.org/projects/katrina/Kingsley.html.

Landphair, Juliette. “'The Forgotten People of New Orleans': Community, Vulnerability, and the Lower Ninth Ward." The Journal of American History, 94 (Dec. 2007): 837-45. Accessed May 10, 2013, http://www.journalofamericanhistory.org/projects/katrina/Landphair.html.

Lo Ricco, Gabriella, and Silvia Micheli. Lo Spettacolo Dell'architettura: Profilo Dell'archistar. Sintesi. Milano: B. Mondadori, 2003. 
MacCash, Doug. "Brad Pitt's Make It Right Affordable Houses Now Available to Teachers, First Responders," NOLA, November 10, 2012. Accessed August 5, 2013. http://www.nola.com/arts/index.ssf/2012/11/brad_pitts_make_it_right_affor.html.

----. "Make It Right at a Crossroads Halfway Through Its Lower $9^{\text {th }}$ Ward Rebuilding Project." NOLA, March 10, 2012. Accessed August 28, 2013. http://www.nola.com/katrina/index.ssf/2012/03/make_it_right_at_a_crossroads.html.

Make It Right. "Architects.” Accessed April 10, 2013. http://makeitright.org/what-we know/library/article/architects/.

Make It Right. "Cradle to Cradle.” Accessed April 9 2013. http://makeitright.org/c2c/.

Make it Right. "Design FAQ-New Orleans." Accessed August 2, 2013. http://makeitright.org/what-we-know/library/article/design-faq/.

Make It Right. "Design Guidelines." Accessed July 29, 2013. http://makeitright.org/wpcontent/uploads/2012/10/Design-Guidelines-Packet-Web.pdf.

Make it Right. "Fort Peck." Accessed July 9, 2013. http://makeitright.org/where-wework/montana/.

Make It Right. "History.” Accessed April 9, 2013. http://makeitright.org/about/history/.

Make It Right. "Kansas City." Accessed July 9, 2013. http://makeitright.org/where-wework/kansas-city/.

Make It Right. "Media.” Accessed August 5, 2013. http://makeitright.org/media/.

Make it Right. "Newark." Accessed July 9, 2013. http://makeitright.org/where-we-work/newark/.

Make It Right. "Staff." Accessed July 29 2013. http://makeitright.org/about/staff/.

McDonough, William, and Michael Braungart. Cradle to Cradle: Remaking the Way We Make Things. New York: North Point Press, 2002.

McLeod, Jerry. "Brad Pitt and Ellen DeGeneres to Host a Star-studded Fundraiser in New Orleans." NOLA, January 26, 2012. Accessed July 30, 2013. http://www.nola.com/celebrities/index.ssf/2012/01/brad_pitt_and_ellen_degeneres.html

Moore, Rowan. "Brad the Builder in New Orleans." The Guardian, March 14, 2010. Accessed April 9, 2013. http://www.guardian.co.uk/artanddesign/2010/mar/14/brad-pittarchitecture-new-orleans.

"Murders in New Orleans were Slightly Fewer in 2012 than in 2011.” NOLA, January 03, 2013. Accessed August 3, 2013. http://www.nola.com/crime/index.ssf/2012/12/murders_in_new_orleans_were_sl.html.

National Association of Home Builders. Accessed July 29, 2013. http://www.nahb.org/generic.aspx?genericContentID=194088.

New Orleans Area Habitat for Humanity. "About Us." Accessed August 28, 2013. http://www.habitat-nola.org/about/.

New Orleans Area Habitat for Humanity. "Facts Sheet." Accessed July 16, 2013. http://www.habitat-nola.org/filestorage/NOAHH\%20Fact\%20sheet\%2006-26-12.pdf.

New Orleans Area Habitat for Humanity. "Home Features." Accessed August 28, 2013. http://www.habitat-nola.org/homeownership/home_features..

New Orleans Area Habitat for Humanity. "Musician's Village.” Accessed April 17, 2013. http://www.habitat-nola.org/about/musicians_village.

NRDC. "LEED Certification information." Accessed April 9, 2013. http://www.nrdc.org/buildinggreen/leed.asp.

"The Pink Project." GRAFT. Accessed April 9, 2013. http://www.graftlab.com/en_index.htm?f=true\#/alph312pink.

Randall, Kate. "City Residents Denounce 'Bring New Orleans Back' Rebuilding Plan. Remaking New Orleans for the Wealthy." World Socialist Web Site, January 14, 2006. Accessed May 9, 2013. http://www.wsws.org/en/articles/2006/01/newo-j14.html. 
Rosenfield, Karissa. "Make It Right Completes Frank Gehry-Designed Duplex," Archdaily, July 17, 2012. Accessed December 2, 2013, http://www.archdaily.com/255147/make-itright-completes-frank-gehry-designed-duplex/.

"Shotgun Houses." Greater New Orleans Community Data Centre. Accessed April 10, 2013. http://www.gnocdc.org/tertiary/shotgun.html.

"Shotgun House." Know LA. Encyclopedia of Lousiana. Accessed July 16, 2013. http://www.knowla.org/image/1276/\&ref=entry\&refID=570.

Smith, Terry. The Architecture of Aftermath. Chicago: University of Chicago Press, 2006.

Stamp, Jimmy. "The Making of a Make It Right House.” Life Without Buildings, July 30 2009, Accessed August 20, 2013. http://lifewithoutbuildings.net/2009/07/the-making-of-amake-it-right-house.html.

Strickland, Edward. Minimalism: Origins. Bloomington and Indianapolis: Indiana University Press, 2000.

Taylor, William. "Shotgun Houses and Housing Projects: Architectural Typology and Memory Techniques of Two New Orleans Reconstruction Scenarios", Interstices 13. Technics, Memory and the Architecture of History (2012), 71-82. Accessed November 20, 2013. http://interstices.ac.nz/wp-content/uploads/2013/05/INT13_02INV_01Taylor.pdf.

“Through the Eye of Katrina: The Past as Prologue?” The Journal of American History 94 (Dec. 2007): 693-876. Accessed May 13, 2013. http://www.journalofamericanhistory.org/projects/katrina/gloss/_neighborhood.html?ke y=lower_ninth

Vidler, Anthony. Architecture between Spectacle and Use. New Haven: Yale University Press, 2008.

Wikipedia. "Lower Ninth Ward.” Accessed July 9, 2013. http://en.wikipedia.org/wiki/Lower_Ninth_Ward.

Williams, Olivia. "Strand East: Ikea Hopes to Build an Entire London Neighborhood." The Huffington Post, October 21, 2011. Accessed August 6, 2013. http://www.huffingtonpost.co.uk/2011/10/21/strand-east-ikeas-london_n_1023421.html.

\section{ABOUT THE AUTHOR}

Sanja Rodeš: PhD Candidate, Griffith School of Environment, Planning and Architecture, Department of Architecture, Griffith University, Gold Coast, Queensland, Australia. 